\title{
Tsukamurella pseudospumae sp. nov., a novel actinomycete isolated from activated sludge foam
}

Correspondence

Michael Goodfellow

m.goodfellow@ncl.ac.uk

\author{
Sun-Woo Nam, ${ }^{1}$ Wonyong Kim, ${ }^{1,2}$ Jongsik Chun ${ }^{1,3}$ \\ and Michael Goodfellow ${ }^{1}$ \\ ${ }^{1}$ School of Biology, University of Newcastle, Newcastle upon Tyne NE1 7RU, UK \\ 2Department of Microbiology, Chung-Ang University College of Medicine, 221 Huksuk-dong, \\ Dongjak-gu, Seoul 156-756, Republic of Korea \\ ${ }^{3}$ School of Biological Sciences, Seoul National University, 56-1 Shilim-dong, Kwanak-gu, \\ Seoul 151-742, Republic of Korea
}

\begin{abstract}
The taxonomic position of two Tsukamurella strains isolated from activated sludge foam was clarified. The organisms, isolates JC85 and $\mathrm{N}^{1176}{ }^{\top}$, were found to have chemical and morphological properties typical of members of the genus Tsukamurella. DNA-DNA relatedness studies showed that the strains formed a distinct genomic species that was most closely related to Tsukamurella spumae. The two isolates also share a range of phenotypic properties that distinguishes them from representatives of all species of Tsukamurella with validly published names. It is evident from the data that the two organisms should be classified as a novel Tsukamurella species, Tsukamurella pseudospumae sp. nov. The type strain is $\mathrm{N} 1176^{\top}$ $\left(=\mathrm{DSM} 44118^{\top}=\right.$ NCIMB $\left.13963^{\top}\right)$.
\end{abstract}

The monospecific genus Tsukamurella was proposed by Collins et al. (1988) for organisms previously classified as Corynebacterium paurometabolum (Steinhaus, 1941) and 'Gordona aurantiaca' (Tsukamura \& Mizuno, 1971). The taxon is well defined and currently encompasses six species with validly published names, namely Tsukamurella inchonensis Yassin et al. 1995, Tsukamurella pulmonis Yassin et al. 1996, Tsukamurella paurometabola (Steinhaus 1941) Collins et al. 1988, Tsukamurella spumae Nam et al. 2003, Tsukamurella strandjordii Kattar et al. 2001 and Tsukamurella tyrosinosolvens Yassin et al. 1997. These species form a distinct clade within the evolutionary radiation occupied by mycolic-acid-containing actinomycetes, i.e. by organisms classified in the suborder Corynebacterineae Stackebrandt et al. 1997. Members of these taxa share very high 16S rRNA gene nucleotide similarity values but can be distinguished by DNA-DNA relatedness and phenotypic data (Kattar et al., 2001; Nam et al., 2003). Tsukamurellae have been described in association with clinical disease (Yassin et al., 1995, 1996, 1997; Kattar et al., 2001) and as agents of foaming in activated sludge plants (Goodfellow et al., 1996, 1998; Seong et al., 1999). Activated sludge foams cause operational problems and may represent a public health hazard because of the potential spread of pathogens by aerosols (Goodfellow et al., 1998).

The GenBank/EMBL/DDBJ accession numbers for the 16S rRNA gene sequences of T. pseudospumae strains $N 1176^{\top}$ and JC85 are AY238513 and AY333425.
The aim of the present study was to establish the taxonomic position of two organisms, represented by strains JC85 and $\mathrm{N} 1176^{\mathrm{T}}$, isolated from activated sludge foam and provisionally labelled 'Tsukamurella spumae' (Goodfellow et al., 1998). It was evident from this study that the two isolates were closely related on the basis of whole-organism pyrolysis mass spectrometric data. In a recent polyphasic study, strain $\mathrm{N} 1176^{\mathrm{T}}$ was distinguished from strains of $T$. spumae and considered to represent a prospective novel species of the genus Tsukamurella (Nam et al., 2003).

The two organisms were maintained as glycerol suspensions $(20 \%, \mathrm{v} / \mathrm{v})$ at $-20^{\circ} \mathrm{C}$ and as glucose/yeast extract agar slopes (Gordon \& Mihm, 1962) at room temperature, as were the type strains of Tsukamurella species (Table 1). Strain JC85 was examined for a combination of phenotypic tests, using standard procedures (Chun, 1995; Nam et al., 2003). Extraction of chromosomal DNA, PCR amplification and the isolation, cloning and sequencing of the amplified 16S rDNA of strain JC85 was carried out following established procedures (Chun \& Goodfellow, 1995). The resultant 16S rRNA gene sequence was compared to corresponding sequences of representatives of the suborder Corynebacterineae as described previously (Nam et al., 2003).

The extent of DNA-DNA relatedness between isolate $\mathrm{N} 1176^{\mathrm{T}}$, isolate JC85 and the type strains of Tsukamurella species was estimated using the fluorometric microplate method (Ezaki et al., 1989), as modified by Goris et al. 
Table 1. Tsukamurella strains included in this study

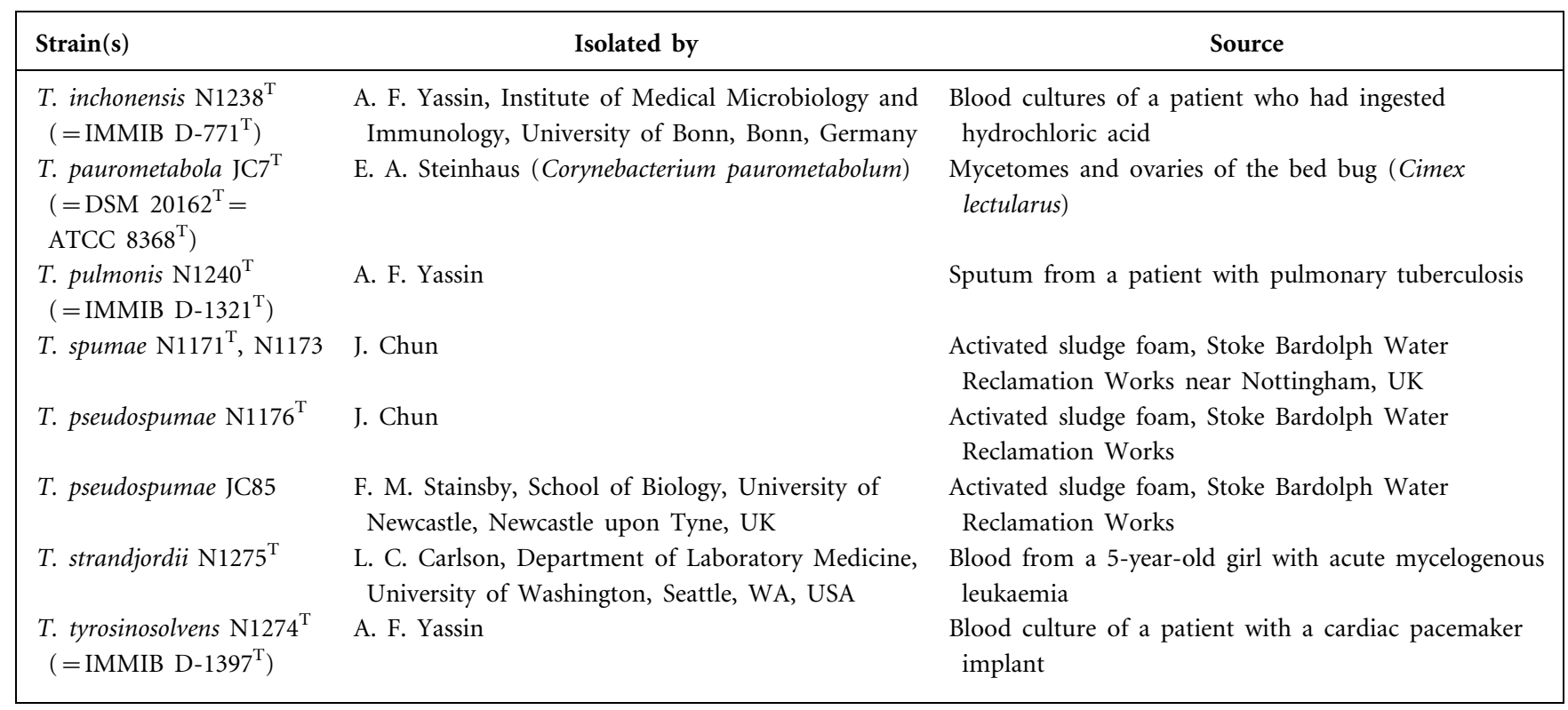

(1998). Photobiotin-labelled DNA from isolate $\mathrm{N}_{1176^{\mathrm{T}}}$ was individually hybridized with single-stranded unlabelled DNA samples of the remaining strains, non-covalently bound to microtitre wells. The hybridization experiments were conducted under stringent conditions in $50 \%$ formamide at $43{ }^{\circ} \mathrm{C}$. Fluorescent intensities were measured using a Fluoroskan CF fluorimeter (Thermo Lab Systems Inc.) at a wavelength of $360 \mathrm{~mm}$ for excitation and $450 \mathrm{~mm}$ for emission. Mean percentage DNA-DNA relatedness values were calculated from triplicate hybridization experiments.

The morphological, degradative, nutritional and physiological properties recorded for isolate JC85 were virtually identical to those reported for strain $\mathrm{N} 1176^{\mathrm{T}}$ (Nam et al., 2003), a result that underpins the close relationship found between these organisms based on Curie-point pyrolysis mass spectrometry (Goodfellow et al., 1998). Strain JC85 was also found to contain meso- $\mathrm{A}_{2} \mathrm{pm}$, arabinose and galactose in whole-organism hydrolysates (wall chemotype IV sensu Lechevalier et al., 1971), $N$-glycolyl residues in the glycan moiety of the cell wall, unsaturated menaquinones with nine isoprene units as the predominant isoprenologue, mycolic acids and major proportions of hexadecanoic $(23.3 \%$ of total fatty acids), oleic $(29 \cdot 9 \%)$ and tuberculostearic $(15 \cdot 2 \%)$ acids. All of these chemical properties are consistent with the classification of strain JC85 in the genus Tsukamurella (Collins et al., 1988; Yassin et al., 1995, 1996, 1997; Kattar et al., 2001).

It is evident from Fig. 1 that strains JC85 and $\mathrm{N}^{1176^{\mathrm{T}}}$ have identical 16S rRNA gene sequences. The mean DNADNA relatedness values and standard deviations found between strain $\mathrm{N} 1176^{\mathrm{T}}$ and $T$. inchonensis $\mathrm{N} 1238^{\mathrm{T}}, T$. paurometabola $\mathrm{JC7}^{\mathrm{T}}$, T. pulmonis $\mathrm{N} 1240^{\mathrm{T}}$, T. strandjordii $\mathrm{N} 1275^{\mathrm{T}}$, T. tyrosinosolvens $\mathrm{N} 1274^{\mathrm{T}}$ and T. spumae $\mathrm{N} 1173$ were $35 \pm 0 \cdot 6,15 \pm 0 \cdot 8,42 \pm 0 \cdot 7,34 \pm 1 \cdot 1,35 \pm 0 \cdot 7$ and $46 \pm 0 \cdot 7 \%$, respectively, values well below the $70 \%$ cut-off point recommended by Wayne et al. (1987) for the

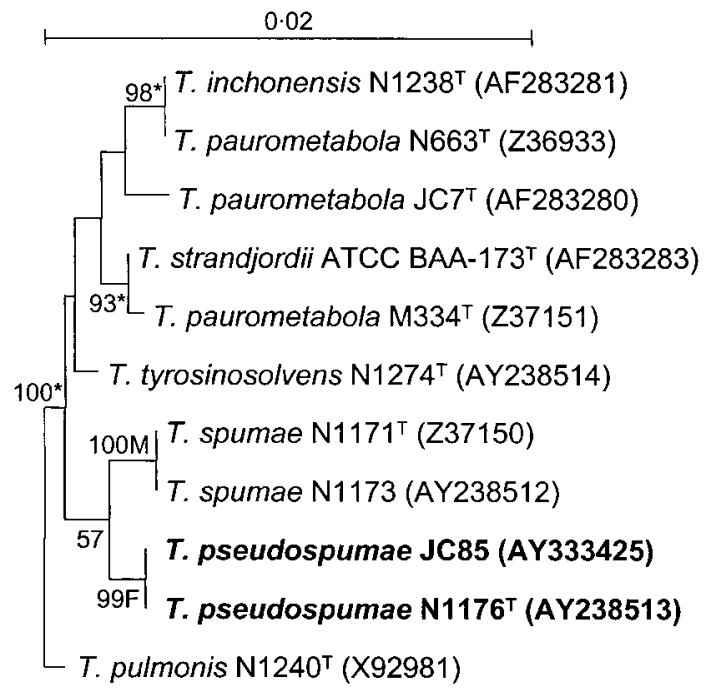

Fig. 1. Neighbour-joining tree (Saitou \& Nei, 1987) based on nearly complete $16 \mathrm{~S}$ rRNA gene sequences showing relationships between strains $\mathrm{JC} 85$ and $\mathrm{N} 1176^{\top}$ and representative strains of Tsukamurella species. Branches of the tree that were also found using the least-squares (Fitch \& Margoliash, 1967) and/or maximum-likelihood (Felsenstein, 1981) treeing algorithms are indicated by asterisks (both algorithms) or by $F$ (leastsquares only) and $M$ (maximum-likelihood only). Numbers at nodes indicate the level of bootstrap support (\%) based on a neighbour-joining analysis of 1000 resampled datasets; only values above $50 \%$ are given. Bar, 0.2 substitutions per nucleotide position. 
Table 2. Phenotypic properties separating strains JC85 and $\mathrm{N} 1176^{\top}$ from the type strains of Tsukamurella species

Taxa are identified as: 1, strains JC85 and $\mathrm{N} 1176^{\mathrm{T}} ; 2$, Tsukamurella inchonensis $\mathrm{N} 1238^{\mathrm{T}}$; 3, Tsukamurella paurometabola

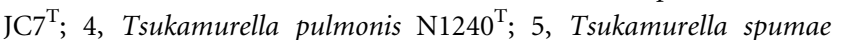
$\mathrm{N} 1171^{\mathrm{T}} ; 6$, Tsukamurella strandjordii $\mathrm{N} 1275^{\mathrm{T}} ; 6$, Tsukamurella tyrosinosolvens $\mathrm{N} 1274^{\mathrm{T}}$. Data for all of the recognized species are taken from Nam et al. (2003). Characteristics are scored as: +, positive; -, negative.

\begin{tabular}{|lcccccccc|}
\hline Characteristic & $\mathbf{1}$ & $\mathbf{2}$ & $\mathbf{3}$ & $\mathbf{4}$ & $\mathbf{5}$ & $\mathbf{6}$ & $\mathbf{7}$ \\
\hline Biochemical tests: & & & & & & & \\
Aesculin hydrolysis & + & + & + & + & - & + & + \\
Urea hydrolysis & - & + & + & + & - & + & - \\
Colour of colonies: & & & & & & & \\
Orange/red & + & - & - & - & + & - & - \\
White/cream & - & + & + & + & - & + & + \\
Degradation tests: & & & & & & & \\
Hypoxanthine & + & + & - & + & + & - & + \\
Tyrosine & + & - & - & - & + & - & + \\
Growth at 10 ${ }^{\circ} \mathrm{C}$ & + & - & + & - & - & - & - \\
Growth on sole carbon & sources & $(1 \%$, & w/v): & & & & \\
D(+)-Arabinose & + & + & - & + & - & - & + \\
L (+)-Arabinose & + & - & - & + & + & - & + \\
D(+)-Arabitol & + & - & - & + & + & + & + \\
D(+)-Cellobiose & - & - & - & + & - & - & + \\
Dulcitol & - & - & - & + & + & - & + \\
meso-Erythritol & - & - & - & + & + & - & + \\
$\mathrm{D}(+)$-Fructose & + & - & + & + & + & - & + \\
$\mathrm{D}(+)-$ Maltose & + & + & - & + & + & - & + \\
$\mathrm{D}(-)$-Mannitol & - & + & + & - & + & + & + \\
$\mathrm{D}(+)$-Melezitose & + & + & - & - & + & - & + \\
$\mathrm{D}(+)$-Melibiose & - & + & + & + & + & + & + \\
$\mathrm{D}(-)$-Ribose & + & + & + & + & + & - & + \\
$\mathrm{D}(+)$-Salicin & - & + & + & + & - & + & + \\
$\mathrm{D}(-)$-Sorbitol & - & + & - & - & + & + & + \\
$\mathrm{D}(+)-$ Xylose & - & + & + & + & + & - & + \\
& & & & & & & \\
\hline
\end{tabular}

delineation of genomic species. In contrast, strains $\mathrm{N} 1176^{\mathrm{T}}$ and JC85 shared a mean DNA-DNA relatedness value of $82 \pm 2 \cdot 0 \%$ and hence are considered to belong to the same genomic species. Strain JC85 shared mean DNA-DNA relatedness values with $T$. inchonensis N663, T. paurometabola $\mathrm{JC7}^{\mathrm{T}}$ and T. spumae N1173 of $22 \pm 0 \cdot 1,14 \pm 0 \cdot 4$ and $58 \pm 1 \cdot 4 \%$, respectively. It can be seen from Table 2 that strains JC85 and $\mathrm{N}_{1176^{\mathrm{T}}}$ share several phenotypic properties that readily distinguish them from representatives of Tsukamurella species with validly published names.

It is apparent from this and earlier studies that strains JC85 and $\mathrm{N}_{1176^{\mathrm{T}}}$ belong to a single species that can be separated from representatives of all species of Tsukamurella using a combination of genotypic and phenotypic data. It is proposed that these organisms be classified in the genus Tsukamurella as Tsukamurella pseudospumae sp. nov.

\section{Description of Tsukamurella pseudospumae sp. nov.}

Tsukamurella pseudospumae (pseu.do.spu'mae. Gr. adj. pseudes false; L. gen. n. spumae of foam and specific epithet of a bacterial species; N.L. n. pseudospumae the false spumae, referring to the close relationship to Tsukamurella spumae).

The description is based on data taken from this and earlier studies (Chun, 1995; Goodfellow et al., 1998; Nam et al., 2003). Aerobic, Gram-positive, partially acid-alcohol-fast, non-motile, non-spore-forming actinomycete, which forms straight to slightly curved rods and a few long filaments, but which does not differentiate into substrate or aerial hyphae. Colonies on glucose/yeast extract agar are large $(<5 \mathrm{~mm})$, orange to red with irregular margins and elevation. Tween 80 and uric acid are degraded but xanthine and xylan are not. Grows at 10,25 and $37^{\circ} \mathrm{C}$, but not at $45^{\circ} \mathrm{C}$. $\mathrm{D}(+)$-Galactose, $\mathrm{D}(-)$-gentiobiose, $\mathrm{D}(+)$ glucose, meso-inositol, $\mathrm{D}(-)$-lactose, $\mathrm{D}(+)$-mannose, $\alpha$-Lrhamnose, $\mathrm{D}(+)$-sucrose, $\mathrm{D}(+)$-trehalose, $\mathrm{D}(+)$-turanose, $\mathrm{D}(-)$-xylitol $(1 \%$, w/v), amyl alcohol, butane-2,3-diol $(1 \%, \mathrm{v} / \mathrm{v})$, sodium citrate and sodium pyruvate $(0 \cdot 1 \%$, $\mathrm{w} / \mathrm{v})$ are used as sole sources of carbon for energy and growth, but adonitol $(1 \%, \mathrm{w} / \mathrm{v})$, butane-1,4-diol, ethanolamine, $\mathrm{D}(-)$-glucuronic acid, methanol $(1 \%, \mathrm{v} / \mathrm{v})$, resorcinol, sodium benzoate and sodium tartrate $(0 \cdot 1 \%$, w/v) are not. L-Asparagine, L-phenylalanine and L-serine are used as sole carbon and nitrogen sources, but L-histidine, L-lysine, succinamide and L-valine are not. Resistant to crystal violet $(0 \cdot 001 \%, \mathrm{w} / \mathrm{v}), 5$-fluorouracil $\left(20 \mu \mathrm{g} \mathrm{ml}^{-1}\right)$, bekanamycin $\left(16,32\right.$ and $\left.64 \mu \mathrm{g} \mathrm{ml}^{-1}\right)$, clindamycin $\left(2 \mu \mathrm{g} \mathrm{ml}^{-1}\right)$, colistin $\left(25 \mu \mathrm{g} \mathrm{ml}^{-1}\right)$, fusidic acid $\left(10 \mu \mathrm{g} \mathrm{ml}^{-1}\right)$, gentamicin sulphate $\left(16\right.$ and $\left.32 \mu \mathrm{g} \mathrm{ml}^{-1}\right)$, kanamycin sulphate $\left(4,8,16\right.$ and $\left.32 \mu \mathrm{g} \mathrm{ml}^{-1}\right)$, nalidixic acid $\left(5 \mu \mathrm{g} \mathrm{ml}^{-1}\right)$, neomycin sulphate $(4,8,16$ and $\left.32 \mu \mathrm{g} \mathrm{ml}^{-1}\right)$, novobiocin $\left(16 \mu \mathrm{g} \mathrm{ml}^{-1}\right)$, oleandomycin phosphate $\left(16,32\right.$ and $\left.64 \mu \mathrm{g} \mathrm{ml}^{-1}\right)$, rifampicin $(0 \cdot 5$ and $\left.2 \mu \mathrm{g} \mathrm{ml}^{-1}\right)$, tetracycline hydrochloride $\left(10 \mu \mathrm{g} \mathrm{ml}^{-1}\right)$ and vancomycin hydrochloride (1, 2 and $\left.4 \mu \mathrm{g} \mathrm{ml}^{-1}\right)$, but susceptible to chlortetracycline hydrochloride (2 and $\left.8 \mu \mathrm{g} \mathrm{ml}^{-1}\right)$, ciprofloxacin $\left(5 \mu \mathrm{g} \mathrm{ml}^{-1}\right)$, erythromycin $(2,4$ and $\left.8 \mu \mathrm{g} \mathrm{ml}^{-1}\right)$, novobiocin $\left(64 \mu \mathrm{g} \mathrm{ml}^{-1}\right)$, penicillin $\mathrm{G}(16$, 32 and $64 \mu \mathrm{g} \mathrm{ml}^{-1}$ ) and rifampicin $\left(8\right.$ and $16 \mu \mathrm{g} \mathrm{ml}^{-1}$ ). Other phenotypic properties are shown in Table 2. Contains mycolic acids with 68-76 carbon atoms and up to seven double bonds; the major products from pyrolysis gas chromatography of methyl mycolates are straightchain fatty acids $\mathrm{C}_{20: 1}$ and $\mathrm{C}_{22: 1}$. Additional chemical markers are typical of members of the genus Tsukamurella.

The type strain is $\mathrm{N} 1176^{\mathrm{T}}\left(=\mathrm{DSM} 44118^{\mathrm{T}}=\mathrm{NCIMB}\right.$ $\left.13963^{\mathrm{T}}\right)$. Strains JC85 and $\mathrm{N}_{1176^{\mathrm{T}}}$ were isolated from activated sludge foam collected from Stoke Bardolph Water Reclamation Works near Nottingham, UK.

\section{Acknowledgements}

J.C. and S.-W.N. were supported by Overseas Research Studentship Awards and W.-Y. K. by a Chevening Scholarship. M. G. and W.-Y. K. 
are also grateful for support from the UK-Korea Science and Technology Collaboration Fund (grant number M1-0027-00-0008).

\section{References}

Chun, J. (1995). Computer-assisted classification and identification of actinomycetes. $\mathrm{PhD}$ thesis, University of Newcastle, UK.

Chun, J. \& Goodfellow, M. (1995). A phylogenetic analysis of the genus Nocardia with $16 \mathrm{~S}$ rRNA gene sequences. Int J Syst Bacteriol 45, 240-245.

Collins, M. D., Smida, J., Dorsch, M. \& Stackebrandt, E. (1988). Tsukamurella gen. nov., harboring Corynebacterium paurometabolum and Rhodococcus aurantiacus. Int J Syst Bacteriol 38, 385-391.

Ezaki, T., Hashimoto, Y. \& Yabuuchi, E. (1989). Fluorometric deoxyribonucleic acid-deoxyribonucleic acid hybridization in microdilution wells as an alternative to membrane filter hybridization in which radioisotopes are used to determine genetic relatedness among bacterial strains. Int J Syst Bacteriol 39, 224-229.

Felsenstein, J. (1981). Evolutionary trees from DNA sequences: a maximum likelihood approach. J Mol Evol 17, 368-376.

Fitch, W. M. \& Margoliash, E. (1967). Construction of phylogenetic trees: a method based on mutation distances as estimated from cytochrome $c$ sequences is of general applicability. Science 155, 279-284.

Goodfellow, M., Davenport, R., Stainsby, F. M. \& Curtis, T. P. (1996). Actinomycete diversity associated with foaming in activated sludge plants. J Ind Microbiol 17, 268-280.

Goodfellow, M., Stainsby, F. M., Davenport, R., Chun, J. \& Curtis, T. P. (1998). Activated sludge foaming: the true extent of actinomycete diversity. Water Sci Technol 37, 511-519.

Gordon, R. E. \& Mihm, J. M. (1962). Identification of Nocardia caviae (Erikson) nov. comb. Ann N Y Acad Sci 98, 628-636.

Goris, J., Suzuki, K. I., De Vos, P., Nakase, T. \& Kersters, K. (1998). Evaluation of a microplate DNA:DNA hybridization method compared with the initial renaturation method. Can J Microbiol 44, $1148-1153$.
Kattar, M. M., Cookson, B. T., Carlson, L. C. \& 7 other authors (2001). Tsukamurella strandjordae sp. nov., a proposed new species causing sepsis. J Clin Microbiol 39, 1467-1476.

Lechevalier, H. A., Lechevalier, M. P. \& Gerber, N. N. (1971). Chemical composition as a criterion in the classification of aerobic actinomycetes. Adv Appl Microbiol 14, 47-72.

Nam, S. W., Chun, J., Kim, S., Kim, W., Zakrzewska-Czerwinska, J. \& Goodfellow, M. (2003). Tsukamurella spumae sp. nov. A novel actinomycete associated with foaming in activated sludge plants. Syst Appl Microbiol 26, 367-375.

Saitou, N. \& Nei, M. (1987). The neighbor-joining method: a new method for reconstructing phylogenetic trees. Mol Biol Evol 4, $406-425$.

Seong, C. N., Kim, Y. S., Baik, K. S., Lee, S. D., Hah, Y. C., Kim, S. B. \& Goodfellow, M. (1999). Mycolic acid-containing actinomycetes associated with activated sludge foam. J Microbiol 37, 66-72.

Stackebrandt, E., Rainey, F. A. \& Ward-Rainey, N. L. (1997). Proposal for a new hierarchic classification system, Actinobacteria classis nov. Int J Syst Bacteriol 47, 479-491.

Steinhaus, E. A. (1941). A study of bacteria associated with thirty species of insects. J Bacteriol 42, 757-790.

Tsukamura, M. \& Mizuno, S. (1971). A new species, Gordona aurantiaca, occurring in sputa of patients with pulmonary disease. Kekkaku 46, 93-98 (in Japanese).

Wayne, L. G., Brenner, D. J., Colwell, R. R. \& 9 other authors (1987). International Committee on Systematic Bacteriology. Report of the ad hoc committee on reconciliation of approaches to bacterial systematics. Int J Syst Bacteriol 37, 463-464.

Yassin, A. F., Rainey, F. A., Brzezinka, H., Burghardt, J., Lee, H. J. \& Schaal, K. P. (1995). Tsukamurella inchonensis sp. nov. Int J Syst Bacteriol 45, 522-527.

Yassin, A. F., Rainey, F. A., Brzezinka, H., Burghardt, J., Rifai, M., Seifert, P., Feldmann, K. \& Schaal, K. P. (1996). Tsukamurella pulmonis sp. nov. Int J Syst Bacteriol 46, 429-436.

Yassin, A. F., Rainey, F. A., Burghardt, J. \& 8 other authors (1997). Tsukamurella tyrosinosolvens sp. nov. Int J Syst Bacteriol 47, 607-614. 